UDK 821.111-2.03=112.2:792(436-89Ljubljana)

\title{
ENGLISH DRAMA AT THE GERMAN THEATRE IN LJUBLJANA IN THE LAST DECADES OF THE HABSBURG MONARCHY
}

\author{
Margarete Rubik
}

\begin{abstract}
This article examines the English repertoire of the German theatre in Ljubljana in the last decades of the Habsburg monarchy and its reception by the local German newspaper, Laibacher Zeitung. It considers only drama, not operas or operettas. The English plays were, of course, performed in translation, in German, as opposed to the plays performed in the Slovenian language from the late $18^{\text {th }}$ century on and especially within the Dramatično društvo circle established in 1867 . The choice of performances gives interesting insights into the late $19^{\text {th }}$ century attitude towards English culture as well as the self-image fostered by the German stage in Ljubljana.
\end{abstract}

Keywords: English theatre, German theatre, Shakespeare, Viennese theatre

Although at the end of the $19^{\text {th }}$ century the Germans were only the third largest ethnic group in Slovenia, their influence on the cultural life was disproportionately high: more than one hundred entertainments, performances, balls and other festivities were organized every year (Matić 343) and played an important role in the identity construction of this minority, which was politically and culturally not marginal in the last decades of the Habsburg monarchy. These theatrical and other popular events helped the German speakers to "preserve their culture by using and cultivating their mother tongue publicly and as frequently as possible (Koter and Virc 278). In 1887 the (German) Ljubljana province theatre burned to the ground, where the Slovenian Philharmonic stands today, which paradoxically gave rise to a quick development of the Slovenian theatre that was opened in 1892, despite the many obstacles the German officials of the dutchy of Carniola (Kranjska) set before it. It was called Kranjsko deželno gledališče during 1892-1919, today it is used for musical performances only and is called Slovensko narodno gledališče Opera in balet (The Slovenian National Theatre Opera and Ballet). The German community wanted to have their own theatre so they raised money and established a new German theatre (called both Deutsches Theater and/or Kaiser Franz Joseph Jubiläumstheater only between 1911-1919), which was active until the dissolution of the monarchy. Today it is the central Slovenian national theatre called Drama Slovenskega narodnega gledališča v Ljubljani (see Miladinović Zalaznik 2008). 
As Dušan Ludvik (165) points out, theatrical activities in Ljubljana date back to the Middle Ages; from 1653 strolling German players occasionally performed in the town, and the Jesuits also staged plays in their college. The German playhouse was opened in 1765, but no early records of the repertoire have survived. Ludvik (170) calls the German theatre an import from a foreign culture and language sphere, but Matić (343) concedes that among its patrons were also members of the Slovenian intelligentsia. At least until 1848, he claims, the theatre did not become involved in nationalist conflicts (Ludvik 171) - but the repertoire even after the Revolution year gives no indication of cultural or political strife or nationalist antagonism. Ludvik in his study also relied on Peter von Radics, who in 1912 wrote the very first study of German theatre in the Slovenian space).

In the archives of the National Museum of Slovenia 2303 playbills from the German theatre have been preserved, but this documentation is incomplete, although many documents could probably still be found in the papers collected by Peter von Radics kept in the National Museum. No records are available of activities before 1886, and only 41 posters have been archived for the years 1886 - 1892 (Koter and Virc 270). It can therefore be assumed that more than 2303 performances took place until the end of the monarchy, when the German theatre closed down. That would mean that about a hundred performances took place each year. Since the theatrical season only lasted eight months, more than ten new plays were performed each month, which must have put a considerable strain on the actors to memorize their lines. The brief runs of the plays were probably due to the small reservoir of potential spectators, although, as mentioned above, educated Slovenians also attended performances at the German theatre. The cast, according to Koter and Virc (278), was fairly multicultural, though the directors were usually German. The theatre cooperated with various other theatres in the Habsburg Empire, but also in Germany, arranging a number of guest performances. There seems to have been little interaction with Slavic culture (Koter and Virc 279) but French and English drama was regularly staged, although plays by English authors constituted only a small percentage of the total repertoire. Of the 2303 playbills, only 40 advertise new productions of English drama.

What role, then, does English drama play in the repertoire of this theatre, which by and large primarily considered itself a vehicle for the dissemination of German culture? What plays were chosen for production (in comparison, for instance, to the Slovenian theatre and to productions in Vienna), and how did the Laibacher Zeitung react to English plays and playwrights?

For any stage in a regional capital the first and foremost consideration would, of course, have been the ability of plays to draw crowds of spectators. Hence the policy of successive playhouse managers in Ljubljana was by necessity a mixture of light entertainment to satisfy the taste of a less sophisticated audience, interspersed with occasional productions of the classics for the social elite and to boost up the theatre's reputation as a serious cultural venue. As Radics (95-127) points out, opera played an important part in the repertoire, already at the beginning of the $19^{\text {th }}$ century. Especially in the second half of the century, English plays were part of the policy of widening the scope of the repertoire, both for the sake of innovation and to create a cosmopolitan atmosphere, though which texts, in particular, were selected for performance must have 
depended not only on the taste of various managers, but also on financial considerations and the availability of actors.

Shakespeare had almost been incorporated among the German classics ever since his plays had been made known to German speakers by the splendid Schlegel-Tieck translations (for detailed studies about Shakespeare's influence on Slovenian playwrights and on Slovenian performances of Shakespeare's productions in Slovenian theatres between 1896-1922 see Jurak). The German theatre prided itself on regular performances of plays by the English bard, whom critics acknowledged as the greatest playwright of all times (Rev. of The Merchant of Venice, 1896) and produced Shakespeare even more often (namely eighteen times in the period surveyed) than the Austrian national playwright Grillparzer, and considerably more frequently than Goethe. Of course the theatre had to make do with limited funds, and had to select plays with an eye to the set and décor needed and the employment of actors suitable for particular roles. For instance, the appearance of guest performers from Vienna or other big theatres inside and outside the Habsburg Empire gave opportunities to stage plays by Shakespeare, Schiller or Goethe for which experienced and particularly gifted actors or actresses were needed. By and large, however, the management of the German Theatre in Ljubljana throughout the period surveyed opted primarily for an "easy-going repertoire" reflecting "the specific cultural atmosphere of the time" (Koter and Virc 277). Koter and Virc hypothesize that such a fairly trivial programme may have served to alleviate the political tensions between German and Slovenian speakers. However, it is more likely that the playhouse managers by performing light hearted comedies and operettas hoped to draw in a wide range of spectators, not only from the German community, but also from other language groups, as Koter and Virc (277) also suggest.

The records in the archives of the National Museum in Ljubljana pertaining to the German theatre only date back to 1886 . However, Radics (99) mentions stagings of King Lear and Hamlet in 1825 and a guest performance of the renowned Viennese actor Löwe as Hamlet in 1849 (120). Besides, a short note of 9 January 1875 in the Laibacher Tagblatt refers to a performance of Shakespeare's Taming of the Shrew (Die bezähmte Widerspenstige), which shows that Shakespearean plays, at least, were presented sporadically throughout the $19^{\text {th }}$ century. The first playbill from the archives referring to an English play at the German theatre is from 3 Nov. 1891 and advertises the staging of Jane Eyre (Die Waise von Lowood), in an adaptation by Charlotte Birch-Pfeiffer (1800-1868), a writer specializing in dramatizations of well-known novels. ${ }^{1}$ Why this, by the time fairly antiquated, play was chosen, is difficult to say. With its mixture of romance and emancipatory rhetoric Charlotte Brontë's novel Jane Eyre, as I have pointed out elsewhere, ${ }^{2}$ nowadays belongs to the most popular canonical English novels. Birch-Pfeiffer's adaptation, however, considerably changed and sentimentalized the plot, turning Rochester's mad first wife into a relative he charitably looks after. In 1891, the play may have been the explicit choice of the Viennese guest performer, Laura Friedländer and/or of the director, a Mr. Thomas, who played Rochester to her Jane. Interestingly, Jane Eyre had been performed only two months earlier at the Volkstheater in Vienna (where it is also the first English play on record), with a dif-

\footnotetext{
${ }^{1}$ Several of her works were performed in Ljubljana in the mid-century (cf. Radics 114 and 118).

${ }^{2}$ See Rubik and Mettinger-Schartmann.
} 
ferent cast, which indicates that the piece must have enjoyed considerable popularity, whatever fault the Ljubljana critics found with it. The National Imperial Stage, the Burgtheater, of all places, had performed the play already in 1853. Remarkably, the play had been staged by the National Slovenian theatre on 8 January 1888, a date preceding the recorded performances both at the German theatre in Ljubljana and the Volkstheater in Vienna, and had been revived in Slovenian in 1889 and twice in 1891, another testimony to the extraordinary appeal the play must have had to audiences across various cultures. Birch-Pfeiffer's Jane Eyre adaptation was given further four new productions at the German theatre in Ljubljana until 1907, more than any single Shakespearean play, and thus was second only to the absolute front runner in popularity, Brandon Thomas' Charley's Aunt, which saw six performances all in all until 1918. When it was first staged under the playhouse management of Alfred Freund in 1894, Brandon Thomas' play ran for an extraordinary four days normally, even repeat performances were rare. Although this farce was so popular in Ljubljana, it was not shown in the prestigious Viennese theatres, which regarded low-brow comedy as too trivial a genre for their venerable halls, but was shown in the Habsburg capital in 1911 by the Theater in der Josefstadt, which at that time had a reputation for specializing in broad farce and popular entertainment.

Another popular sentimental play performed at the German theatre on 11 January 1895 was the dramatic adaptation of Hodgson Burnet's Little Lord Fauntleroy, which had been put on in the Vienna Volkstheater only a few weeks previously, on 28 Dec. 1895, and had had an extraordinary successful run of 57 performances. The fact that the Ljubljana production followed so quickly on the heels of the Vienna staging indicates that the managers in Ljubljana kept their eyes on metropolitan tastes and tried to keep abreast of what was fashionable and successful in the big cities. ${ }^{3}$ Also popular - both with German speaking and Slovenian audiences in Ljubljana were dramatic adaptations of the adventures of Sherlock Holmes, which indicates the international appeal of the famous English detective.

In the long run, Shakespeare was, of course, the most frequently performed British playwright even in the German theatre in Ljubljana in the last three decades of the Habsburg monarchy (as, indeed, he was in the Slovenian National Theatre; for a detailed study of Shakespeare's performances and influences in Slovenia see Jurak 2009 , 2010). Shakespeare's individual plays, however, were upstaged in popularity and the number of productions in the German theatre by Charley's Aunt and Jane Eyre. By comparison, in Vienna the Burgtheater almost exclusively concentrated on the Bard in its English repertoire (bringing out 21 productions between 1891 and 1916). The Volkstheater followed suit with 14 productions of different Shakespearean plays in the course of this period, although after the turn of the century Shaw outrivaled the Elizabethan playwright in popularity and the number of productions there. A comparison between the repertoire of the Volkstheater and the German theatre in Ljubljana shows some noteworthy similarities: all in all, 40 English plays

\footnotetext{
${ }^{3}$ The play was performed in Hungarian at the Theater in der Josefstadt in 1912. The fact that in the $19^{\text {th }}$ century the German stage in Ljubljana was both modelling itself and also competing with Viennese stages is also evident from Radics' pride, in 1912, that Schiller's Wilhelm Tell had been performed in Ljubljana in 1826, one year before its Vienna premier (Radics 99).
} 
were staged at the German theatre in Ljubljana, and 40 at the Volkstheater, where the records date back to 1889. The choices made from the Shakespeare canon were also similar, though the Volkstheater in addition to the plays popular in Ljubljana also staged, for instance, Twelfth Night, Richard III and The Winter's Tale. The Shakespearean plays selected for production at the German theatre in Ljubljana comprise only a very limited range of his complete works. Hamlet, considered to be Shakespeare's greatest tragedy, of course had to be part of the repertoire and saw at least four productions all in all (three in the period surveyed and one in 1825 mendioned by Radics (99). It is understandable that a play like The Taming of the Shrew, containing broad comedy and therefore possibly attractive to a wider audience, should have been staged thrice - though the play is seldom performed nowadays. It is also no wonder that the magic and romance of A Midsummer Night's Dream should have delighted the audience, or that Romeo and Juliet was popular. Both plays were also performed three times in the period surveyed. It seems remarkable, however, that The Merchant of Venice was also staged thrice at the German theatre in Ljubljana. As will be analyzed in greater detail below, reviews suggest that the figure of the Jew exerted a particular fascination, in spite of - or perhaps because of - the growing wave of anti-Semitism in the Habsburg Empire around the turn of the century. Other Shakespearean works, such as the histories and Roman plays, and even some of the famous comedies, such as As You Like It, Much Ado About Nothing, or Twelfth Night, were never performed at the German theatre.

The theatre manager Karl Dietrich must have been particularly Anglophile. In the half year of his time in office, no less than six English plays were staged, four of them by Shakespeare. In contrast, his successor, Berthold Wolf, who stayed in office for 9 years and who is said to have broadened the repertoire by including plays from various nationalities (Koter and Virc 277), at first seems to have taken no interest in English drama, until he suddenly brought out no less than six English plays in 1907. During his time in office, only four Shakespearean plays were performed, but, apart from some light comedies, Wolf introduced the Ljubljana audience to Oscar Wilde and G. B. Shaw. Theatre goers became acquainted with Wilde through two performances of An Ideal Husband and a dramatic version of The Picture of Dorian Gray, all in the same year 1907, the former being put on again in 1913, when it was also brought out on the Slovenian stage. An Ideal Husband had scored a spectacular success with 114 performances at the Theater in der Josefstadt from November 1906 on, as part of an attempt of the new manager, Josef Jarno, to raise the quality of the repertoire, and the German Theatre in Ljubljana (whose repertoire, despite its penchant for the light muse, was certainly more canonical by and large) closely followed suit in January 1907, probably drawn to the play by its remarkable popularity in the capital. Since the Theater in der Josefstadt had first staged this comedy of manners with great success, the play was not performed at the Volkstheater, where Wilde was represented instead by The Importance of Being Earnest and A Woman of No Importance, in 1905 and 1907 respectively. The Burgtheater, which generally concentrated on the classics, somewhat belatedly produced An Ideal Husband in 1910, after staging Wilde's fragment A Florentine Tragedy in 1909. 
In 1907, German theatre audiences in Ljubljana were also introduced to G. B. Shaw, namely to his Mrs Warren's Profession, for the first and only time, which is surprising, given the popularity on the Vienna stages of a playwright especially beloved by the Germans. In the pre-war years, even the Burgtheater brought out 3 Shavian plays, and the Volkstheater staged no less than 6 plays by Shaw between 1907 and 1909, and was to produce two more in 1911 and 1913. Even the Theater in der Josefstadt, normally given to very light fare, produced four Shavian plays between 1904 and 1917. Shaw seems to have been much less popular in Slovenia, though, remarkably, Ljubljana had for once beaten the metropolis in bringing out Mrs Warren's Profession, since in the Volkstheater it was on only in 1908.

Other instances of plays performed in close temporal proximity, first in Vienna, then in Ljubljana, were Jerome K Jerome's farcical Miss Hobbs (performed both at the Volkstheater and the German theatre in Ljubljana in 1902) and J. M. Barrie's sentimental comedy The Little Minister (staged both at the Burgtheater and the German theatre in 1908). This again suggests that the management of the German theatre kept an eye on the goings-on in the capital and, when possible, aligned its repertoire of new plays with what was happening in Vienna. In the case of performances of Shakespearean drama, however, there is no such close correlation. To be sure, A Midsummer Night's Dream was performed at the Burgtheater in December 1894 and three months later in Ljubljana, but the rest of the Shakespearean stagings at the German theatre in Ljubljana were not synchronous with Vienna. A provincial theatre could hardly hope to imitate the metropolitan models since the range of actors available and the money that could be spent on a production was limited. Also as far as the Slovenian stages were concerned, the repertoire differed substantially from the German rival institution: although Shakespearean plays were performed less often in Slovenian, the Shakespeare canon shown was more diversified, ranging from such popular plays as Romeo and Juliet or The Merchant of Venice, to little performed plays such as The Comedy of Errors and Julius Caesar, neither of which were ever produced at the Ljubljana German theatre. Inevitable staples like Charley's Aunt, Jane Eyre, or Little Lord Fauntleroy, were also performed in Slovenian, just like adaptations of the Sherlock Holmes stories (also popular at the German theatre), as well as Wilde or Somerset Maugham, but the repertoire also included melodramatic historical plays by Barret Wilson (Quo Vadis; The Sign of the Cross). It is therefore unlikely that the two rival Ljubljana stages should have imitated one another or come to any agreement as to the choice of the English repertoire.

Critics of the Laibacher Zeitung (see Miladinović Zalaznik 2000) usually complained about the predominance of the "harmless light genre" (Rev. of Hamlet, 1895) in the repertoire of the German theatre, and commended the courage of directors and managers who ventured upon high literature, such as Shakespeare, Schiller, Goethe or Grillparzer. When the German theatre remained half empty for a performance of Hamlet, the theatre public was chided for missing this "noble intellectual stimulus" (Rev. of Hamlet, 1895) ${ }^{4}$. To the immense satisfaction of the reviewer, a large and enthusiastic crowd had turned up for the performance of The

${ }^{4}$ All quotes from the reviews in the Laibacher Zeitung have been translated into English by the author. 
Merchant of Venice in 1896, despite the fact that prices had been "extraordinarily" raised. ${ }^{5}$ Similarly, it was commended that in spite of the unpropitious date on Ash Wednesday, a fairly large audience had appeared to see Romeo and Juliet, thereby proving their "sense for the eternally true and good" (Rev. of Romeo and Juliet, 1900). Critics were always at pains to stress that the classics, too, will be greeted with enthusiasm, and that their production is not only a noble, but also a lucrative task (Rev. of Hamlet, 5 March 1908). In the follow-up review, a defender of high culture once more exclaimed against the "tedium of the light muse" which was the usual fare in the German theatre (Rev. of Hamlet, 6 March 1908).

Such support for the classics was, of course, not confined only to the English canon. Critics were equally enthusiastic about Schiller, Goethe, Lessing or Grillparzer. The reviews especially of Schiller-performances frequently stress the young spectators' "ardent enthusiasm" as proof that the great works of canonical playwrights will be appreciated (Rev. of Braut von Messina). The actors who acquitted themselves well in a performance of Lessing's Nathan der Weise, in turn, served as proof that the cast could do better than confine themselves to insipid farce (Rev. of Nathan der Weise). On 20 Nov 1900 the review waxed enthusiastic about the charming staging of The Midsummer Night's Dream, which made one forget "the sirens' songs of the light muse". The same phrase was used again a few years later in a review of Romeo and Juliet (1908). Indeed, throughout the decades, the attitudes of the critics hardly changed. The German theatre in Ljubljana, it was felt, ought to have started the season of 1902/03 with a worthier (i.e., classical) play than Miss Hobbs, a farce which supposedly boasted of little originality but a lot of ribald humour (Rev. of Miss Hobbs) - always considered an undesirable quality. Indeed, hefty jokes generally failed to please the taste of the reviewers, even when they came in the shape of popular Austrian folk comedy such as Nestroy's Der Zerrissene (Rev. of Der Zerrissene) or the widely popular Lumpacivagabundus, which was classified as "funny", but "certainly not based on good taste" (Rev. of Lumpacivagabundus). ${ }^{6}$

As was to be expected in a climate of such enthusiasm for the classics, Shakespeare held extremely high cultural prestige, and his works and dramatis personae were constantly characterized as deeply complex and hence difficult to perform on a provincial stage, without first class actors. Hamlet, for instance, was called a tragedy too deep to fathom (Rev. of Hamlet, 1895), and was considered to be Shakespeare's "greatest and deepest play" (Rev. of Hamlet, 5 March 1908). But Goethe's Faust, too, was regarded as one of the most difficult plays in world literature, which no-one had yet fathomed (Rev. of Faust, 1912). Perhaps surprisingly, Petruchio was also considered to be one of the most difficult roles in dramatic literature, because of the wide gap between contemporary attitudes to marriage and the "medieval" views of the Bard (Rev. of The Taming of the Shrew, 1893), which can easily make The Taming of the Shrew degenerate into burlesque. Othello was said to send "a tragic shiver" down one's spine (Rev. of Othello, 1899). Romeo and Juliet was praised for

\footnotetext{
${ }^{5}$ Generally, seats for opera were more expensive than for plays, and tickets could also be raised e.g. for benefice nights (Radics, 105).

${ }^{6}$ Radics reports that Lumpacivagabundus in 1835 caused a riot of tailors, who protested against a salacious song sung by the actor playing Zwirn, the tailor, on stage.
} 
its "exalted poetry" (1900) and for its "lyrical beauty" (1901) and was called the bard's most perfect masterpiece (1908). The reviewer also celebrated the poetry and fine humour of A Midsummer Night's Dream (1895).

Critics for the Laibacher Zeitung frequently seem to have looked down upon provincial stages and to have taken their standards from the big theatres in the German-speaking cities, particularly from Vienna. They kept repeating that performing Shakespeare was a difficult undertaking for a provincial theatre, since sophisticated scenery and great actors would be needed (Rev. A Midsummer Night's Dream, 1895, 39). Frequently, they condescendingly acknowledged the plodding exertions of the provincial actors, since no more was to be expected from their limited talents. This patronizing tone was adopted, for instance, in a review of another production of $A$ Midsummer Night's Dream: in a provincial theatre, it was felt, one had to be satisfied when the "kernel" of a play was preserved, the language not mutilated, and the action not held up by the staging. The German theatre in Ljubljana could not hope to meet the demands for décor and theatre machinery necessary for a really professional production of the play, but, it was condescendingly added, the performance was "pretty" enough, although the actors were mediocre (Rev. of A Midsummer Night's Dream, 1907).

In general, the theatre reviews in the Laibacher Zeitung give the impression that the critics were unwilling to let any production off completely unscathed - if they had nothing else to criticize, they complained about the long intermissions and the overheated theatre (Rev. of Romeo And Juliet, 1900). Most of the complaints, however, referred to the faults of the actors and absurdities of the production. Since the exalted language of the classics gave rise to particular enthusiasm on the part of the critics, it is not surprising that a frequent cause for censure was the indistinct pronunciation of actors and their inability to do justice to verse. Thus the reviewer of a performance of Hamlet criticized the actors' lack of modulation (Rev. of Hamlet, 1895). In contrast, Miss Werney as Julia was celebrated for her "wonderful rendering" of Shakespearean verse, which she made sound like music (Rev. of Romeo and Juliet, 1908). The cast in A Midsummer Night's Dream of 1899 were admonished for not learning their lines properly (20 Nov 1899, 2116). The performers of the 1907 production of An Ideal Husband did not speak distinctly enough, so that some of Wilde's humour was lost and the scenes became boring (18 Jan 1907, 130). A Mr Mraschner - evidently no native German speaker - who took a role in The Merchant of Venice, was censured for pronouncing ü like i (3 Feb. 1911, 241). A North German accent, however, was also considered offensive (Rev. of Faust, 1912) - an indication that the ingrained dislike of the Austrians for the "Prussians" was palatable also on the periphery, in Ljubljana, despite the political alliance of the two states.

Those plays which were no classics usually met with a less friendly reception. Jane Eyre, which was popular for years at the German theatre in Ljubljana, was rejected as a sample of Birch-Pfeiffer's worn-out oeuvre dug out from dusty archives, with an unconvincing main character. At least the actors of the 1891 performance, it was acknowledged, avoided pathos and sentimentality (Rev. of Jane Eyre, 1891). The attack on the play was repeated in 1897, when the reviewer would have preferred a classic for a guest performance. Young people, it was claimed, 
want to hear "the hot breath of convincing eloquence" and intellectual challenge, instead of this old-fashioned "warmed-up romantic porridge" (Rev. of Jane Eyre, 1897, 47). The audience, however, seems to have liked the play and the histrionic performance style and rewarded the actors with enthusiastic applause. In 1907, Jane Eyre was again ridiculed as part of Charlotte Birch-Pfeiffer's band-conveyor literary production, an "incredibly trivial" work written for a naive audience, on a topic which may have moved our ancestors to tears but seems ridiculous to us nowadays (Rev. of Jane Eyre, 1907).

In contrast to the reception of Jane Eyre, the "pretty comedy" Little Dorrit, adapted from Dickens' novel and equally sentimental, pleased both the reviewer and the scanty audience who had turned up for the occasion (Rev. of Little Dorrit). The critic, on the other hand, could not see why audiences should have taken an interest in the dramatic version of Little Lord Fauntleroy and its depiction of the conflict between British aristocrats and American democrats, but he approved of the affecting tone and the celebration of the love between mother and child, and hence concluded that the play did not deserve the condemnation it had met with in Vienna (Rev. of Little Lord Fauntleroy, 1896). Later, the play was classified as a "harmless sentimental comedy", pleasing to the audience, although being full of "terribly good people" who, at least in the theatre, are rarely as interesting as evil ones. The second act, in which the boy wins his grandfather's heart, was commended as "touching", while the sensationalism of the third act met with disapproval (Rev. of Little Lord Fauntleroy, 1900).

Charley's Aunt was tolerated as a carnival joke, possibly because, as is noted explicitly, it had also been successful in Vienna (Rev. of Charley's Aunt, 1894). Its hefty humour was not really to the critic's taste, but the comedy scored with the audience through its effective situation comedy. The patronizing tone adopted by the reviewer is typical of the attitude the Laibacher Zeitung took towards light comedy and popular culture. In 1896, the critic was equally sceptical. Again, the scanty plot and the "ribald style typical of English humour" were mentioned, though it was conceded that the actors made the well-known farce, which had become popular on German stages, seem funny (Rev. of Charley's Aunt, 1896). Equally condescending was the reaction to the dramatized version of Sherlock Holmes one of the actors had chosen for his benefit night, which was considered to be food mainly for sensationhungry spectators (Rev. of Sherlock Holmes).

On the other hand, Mrs. Warren's Profession found approval, since it came from the pen of "a brilliant playwright" and was said to widen the horizon of the audience (Rev. of Mrs. Warren's Profession, 17 Oct. 1907). The follow-up review on the next day was more cautious. Shaw was carefully set off from those modern playwrights who scavenge moral degeneration to find topics for their works, because - as the critic commends - he takes a socially critical view and castigates the lax morality of the English upper class. Besides, he adds with self-congratulation, "we are not philistines, like our grandparents" and realizes that "art must address conflicts in all areas of life" (Rev. of Mrs. Warren's Profession, 18 Oct. 1907). Such pride in the supposed progressiveness of the age can be found in several reviews. The fact that critics were not hostile on principle to problem plays tackling taboo 
subjects had already been evinced by the positive review of Ibsen's Nora, in spite of its provocative treatment of marriage and of the "awakening of a woman's serious self-awareness" (Rev. of Nora).

In contrast, surprisingly, the plot of An Ideal Husband was rejected as being in the French style (which must have meant: concerned with sexual intrigue), though made more winning through sarcasms and aphorisms. Oscar Wilde, it was acknowledged, was no moralist, but ridiculed the triviality of English upper class society with "amiable unselfconsciousness" (Rev. of An Ideal Husband, 1907) not a term one would nowadays want to apply to Wilde. It is the style, the critic maintained, that makes the play attractive, not its plot. Unfortunately, the actors did not speak distinctly enough, which ruined the effect of the scenes. Dorian Gray was also received with mixed feelings. The critic did not really know what to make of this "mixture of the sensational and the supernatural" (Rev. of Dorian Gray, 28 Nov. 1907). The audience, too, seems to have rejected George Bentley's adaptation of Wilde's famous novel. In a more extended review on the next day, it was castigated as a "horrible play" although it came from the pen of "one of the most genial new dramatists" (Rev. of Dorian Gray, 29 Nov. 1907). Its success in Vienna was ascribed to the fact that the metropolitan audience must have known the novel, with which spectators in Ljubljana were unfamiliar. The dramatic version mangled the exquisite character portrayal, turning Wilde's sparkling world view into kitsch and mere English spleen. It was unfortunate, the critic complained, that the brilliant British dramatist was only known in Slovenia through his Ideal Husband, which, as has been shown above, had received a negative reception in Ljubljana in the same year 1907. Six years later, the harsh criticism had been forgotten and the reviewer assured the readership that a new production of An Ideal Husband confirmed the positive impression the play had made some years ago (Rev. of An Ideal Husband, 1913) - a rare case of an evaluation reversed within a relatively short span of time, proving that, although critical tastes often remained stable for decades, the reaction of the reviewers was not always predictable. Thus, despite their dislike of light comedy, Barrie's The Little Minister was considered a good choice, when compared to French fashions (associated invariably with sensationalism and the breaking of sexual taboos). The play was welcome as a fairy tale full of sentiment and warmth, challenging tears of emotion and delightful for its unsophisticated humour (Rev. of The Little Minister).

In general, these reviews give only a very limited insight into the actual way in which plays were staged or characters interpreted; we can gain but fleeting impressions of the performances through such criticism. A Mr. Pregler in 1895, for instance, played Hamlet as a man of "sophisticated deliberation" and "sharp intellect," not as a melancholic, whereas, much to the amazement of the critic, Ophelia was portrayed as a sentimentalist (Rev. of Hamlet, 1895). In 1899, a Mr. Kirsch presented the Danish prince not as a melancholic either, but as a man working unscrupulously for his aim of revenge (Rev. of Hamlet, 1899). The actors in the 1908 production of Hamlet were criticized for slavishly following the old models (whatever these may have been), without attempting to adapt to modern attitudes or considering that such antiquated styles might cause unexpected bursts of exhilaration (Rev. of 
Hamlet, 6 March 1908). Such mistakes, the critic lectured in the hope of improving the quality of productions in the future, could have easily been avoided - giving one of the most detailed descriptions of a performance of Shakespeare that we have. The ghost entered in a ridiculous veil instead of an armour, and for obscure reasons his encounter with Hamlet was split into two parts, one taking place in the castle, one in a wood. The play within the play was performed at the extreme side of the stage, so that half the audience could not see what was happening. Absurdly, Hamlet looked behind the curtain before stabbing Polonius. The set was too shabby for a King's palace. The actor impersonating Hamlet interpreted the Prince as a man of quick action, not of hesitation and indecision, and spoke so indistinctly as to be incomprehensible, hurrying over Shakespeare's magnificent verses, though "each word expresses golden wisdom" (6 March 1908, 478). The leading actress lacked the maturity and experience required for the role of Ophelia, playing her too demurely. Polonius was too jovial, the Queen too superficial, an actress forgot her text and all minor roles were unsatisfactory.

Slating reviews also abound in other cases, affording brief glimpses of the performance practices at the German theatre. The actor performing Othello was criticized for his histrionics (Rev. of Othello, 1899); similarly, the performer taking the title role in An Ideal Husband was said to act too pathetically, and the other thespians supposedly tried the patience of the audience - for what reason, is not made quite clear, probably for not speaking distinctly (Rev. of An Ideal Husband, 1907). Demetrius and Lysander in the 1895 production of A Midsummer Night's Dream did not find the appropriate comic tone (Rev. of A Midsummer Night's Dream, 1895), whereas Ernst Hartmann threw the audience into "raptures" as Petruchio because he turned him into an attractive comic figures, quickly passing over the character's brutality and concentrating on his "tender geniality" - a somewhat unexpected description of Petruchio's behaviour. Miss Jenbach's Catherine, on the other hand, was considered to be "too ribald" (Rev. of The Taming of the Shrew, 1893).

The set occasionally also came in for its share of criticism. Thus a niggling reviewer took offense at the worn-down carpet leading to Theseus' throne in the 1899 staging of A Midsummer Night's Dream (20 Nov 1899, 2116). Similarly, the props were too shabby for a King's palace in Hamlet (19 March 1908, 471). ${ }^{7} \mathrm{Al}$ though the 1908 production of Romeo and Juliet was praised for relying more on the imagination than on decorations and sets, this supposedly did not work well for the masked ball (Rev. of Romeo and Juliet, 1908). The production of Mrs. Warren's Profession seems to have failed to make the milieu of Shaw's play unequivocally clear, and the actress playing the main part was felt to look too respectable for the madam of a brothel. Mishaps also happened in other productions of the classics. Thus Gretchen's room in Faust, to the scorn of a reviewer, was anachronistically lit by a modern lamp (Rev. of Faust).

There are few reviews in the Laibacher Zeitung of performances in the Slovenian Theatre in Ljubljana, but notice was taken of Othello. Although "a single

\footnotetext{
${ }^{7}$ The precarious financial situation of the theatre is also illustrated by a humorous mid-century episode recounted by the famous actor Karl Basel: as the theatre did not provide him with an appropriate $18^{\text {th }}$ century costume, he helped himself by using a lady's underpants as a jabot (qt. Radics 126).
} 
mistake" might have made the whole performance ridiculous, the actors acquitted themselves creditably and played with "fire". Fault was only found with the haphazardly jumbled costumes (Rev. of Othello, 1896). The staging of The Merchant of Venice at the Slovenian theatre was not considered to be equally successful, especially in the depiction of the minor roles - which, according to the patronizing critic, was no wonder, since Shakespeare posed great difficulties to small theatres, which tend to show only a distorted image of the great bard's art. The actors at the Slovenian theatre, however, avoided "the worst", the critic added approvingly (Rev. of The Merchant of Venice, 1897).

The interpretations Shylock was given in the German theatre in the period surveyed deserve special attention. In 1896, The Merchant of Venice was considered to be one of Shakespeare's least accessible plays. The Jew was seen as a complex character eaten up by religious hatred and demoniac malice on the one hand, but also endowed with noble reserve (26 March 1896, 554), which the actor, a Mr. Lewinsky, who specialized in the impersonation of demonic characters, could not quite bring across. It is particularly interesting to compare two later reviews reacting to performances of The Merchant of Venice in two consecutive seasons under the management of Karl Richter. The reviewer "P" in 1911 regarded the Jew as a tragic figure who, at the climax of his revenge, is cast into the dust and in his despair even promises to abandon his faith. Next to Lessing's Nathan, P opines, Shylock is the most touching embodiment in world literature of "the fate of this singular race." By contrasting the ancient Jewish concept of law with the ideal of mercy, Shakespeare addressed "the deepest problems of religious history." In Shakespeare's less refined age, $P$ explains, Shylock was considered a figure of fun, though he seems tragic to us today. Instead of reacting to the Jew with glee, "we" have learned to put ourselves into the place even of a despised people and "we" no longer laugh at the suffering of a man, though he himself may be partly responsible for his fate. Joseph Beck's impersonation of the figure was praised, though his youth supposedly prevented him from presenting Shylock's thirst for revenge convincingly. Shylock, the reviewer argued, must be made to seem a "volcano of century-old hatred, who in between metamorphoses into a whining dog" - a metaphor which makes one doubt the liberalism and tolerance of the critic after all (3 Feb. 1911, 241).

In contrast, in 1912, critic "J", though praising The Merchant of Venice as a "grandiose play" deserving a place in the repertoire of every sizable playhouse, interpreted Shylock as a "horrible villain" motivated by relentless hatred, not as a tragic hero deserving of our pity. Quite on the contrary, he ought to arouse anger and repugnance, and Portia's judgment should be accepted with satisfaction by the audience. In accordance with this anti-Semitic stereotype, Mr. Grine played the Jew with "gnashing teeth, cowering, staring with a poisonous gaze, full of hatred and anger at his oppressors" - the reason for this hatred being "the aversion of the usurer to the morally superior Antonio" (14 Dec 1912, 2773). The two reviews following each other in such quick succession map out the ideological conflicts over anti-Semitism at the time.

Although these reviews allow us some insight into the political, and sociocultural debate of the time, the German theatre in Ljubljana in the last decades of 
the Habsburg monarchy was not regarded as a vehicle for political comment, but as a place of escapist amusement or bourgeois cultural exercise. Critics did not try to establish connections between the plays performed and the political or social context of their time. This would hardly have been possible with such pieces as Charley's Aunt, Jane Eyre or Sherlock Holmes. But neither was it attempted for Shakespearean plays or for Schiller - and the latter, in particular, would have afforded ample food for political propaganda. On the contrary, critics seemed to emphasize that the conflict between the English and the Americans in Little Lord Fauntleroy, for instance, was too far removed from continental experience and did not interest the local audience, or that Wilde criticizes the triviality of the English upper class. Even when the topical subject matter in Nora or Mrs. Warren's Profession are discussed, this does not seem to lead to a genuine schema disruption as regards patriarchal attitudes at home - quite on the contrary, critics frequently wax complacent at the age's supposed progress in tolerance and understanding. The same holds true for The Merchant of Venice: although the reviews allow glimpses of anti-Semitism, they show no awareness that the hostile attitude towards Jews was a contemporary problem as well. Plays performed by the German theatre in Ljubljana in the last decades of the Habsburg monarchy were thus escapist entertainment or a bourgeois exercise of immersion into world literature, not only as far as the English Repertoire is concerned.

University of Vienna, Austria

\section{WORKS CITED}

Bauer, Anton, and Gustav Kropatschek. 200 Jahre Theater in der Josefstadt. Vienna: Schroll, 1988. von Alth, Minna. Burgtheater 1776-1976. Aufführungen und Besetzungen von 200 Jahren. Vol. 1. Vienna: Ueberreuther, 1978.

Jurak, Mirko. "William Shakespeare and Slovene Dramatists (I) : A. T. Linhart's Miss Jenny Love.“ Acta Neophiloogica 42.1-2 (2009): 3-34.

"William Shakespeare and Slovene Dramatists (II) : J. Jurčič, F. Levstik, I. Cankar, O. Župančič, B. Kreft ." Acta Neophilologica 43/1-2 (2010): 3-48.

"William Shakespeare and Slovene Dramatists (III): (1930-2010).“ Acta Neophilologica 44.1-2 (2011): 3-34.

"Jakob Kelemina on Shakespeare's Plays." Acta Neophilologica 40. 1-2 (2007): 5-49.

Koter, Darja, and Benjamin Virc. "The collection of playbills at the German Theatre in the archive of the Narodni muzej Slovenije in Ljubljana - A documentation of the theatrical production between 1886 and 1914." Musik-Sammlungen - Speicher interkultureller Prozesse. Ed. Erik Fischer. Vol. A. Stuttgart: Steiner, 2007. 267-82.

Ludvik, Dušan. "Nemško Gledališče v Ljubljani do 1790.” Diss. U of Ljubljana, 1957.

Miladinović Zalaznik, Mira. "Das Revolutionsjahr 1848 in den Laibacher Blättern, Laibacher Zeitung, Illyrisches Blatt und Kmetijske in rokodelske novice." In: Amann, Klaus (Hg.), Lengauer, Hubert (Hg.), Wagner, Karl (Hg.). Literarisches Leben in Österreich : 1848-1890. Wien [etc.]: Böhlau, cop. 2000, S. [601]-623.

"Das einzige Wort 'svinja' (Schwein) welches vorkam [...] kann man [...] verzeihen, ohne daß [...] die Ehre der slovenischen Nation darunter leidet" : slowenisches Theater des 19. Jahrhunderts. V: Bobinac, Marijan (ur.), Müller-Funk, Wolfgang (ur.). Gedächtnis - Identität - Differenz : zur kulturellen Konstruktion des südosteuropäischen Raumes und ihrem deutschsprachigen 
Kontext ; Beiträge des gleichnamigen Symposiums in Lovran/Kroatien, 4.-7. Oktober 2007, (Kultur - Herrschaft - Differenz, Bd. 12). Tübingen: Francke, 2008, str. 73-83.

Matić, Dragan. "Kulturni utrip Ljubljane med prvo Svetovno vojno, Kulturne in družabne prireditve v sezonah 1913/14 - 1917/18." MA thesis. U of Ljubljana, 1995.

Radics, Peter von. Die Entwickelung des deutschen Bühnenwesens in Laibach. Kulturbilder anläßlich der Eröffnung des Kaiser Franz Joseph-Jubiläumstheaters. Laibach: Selbstverlag 1912.

Rubik, Margarete, and Elke Mettinger-Schartmann. Introduction. A Breath of Fresh Eyre. Intertextual and Intermedial Reworkings of Jane Eyre. Ed. Margarete Rubik and Elke Mettinger-Schartmann. Amsterdam: Rodopi, 2007. 9-21.

Teichgräber, Axel. "Das 'deutsche' Volkstheater und sein Publikum.” Diss. Vienna U, 1965.

Rev. of A Midsummer Night's Dream, by William Shakespeare. Laibacher Zeitung 3 Oct. 1907: 2112.

Rev. of A Midsummer Night's Dream, by William Shakespeare. Laibacher Zeitung 28 March 1895: 592.

Rev. of An Ideal Husband, by Oscar Wilde. German Theatre, Ljubljana. Laibacher Zeitung 18 Jan. 1907: 130.

Rev. of An Ideal Husband, by Oscar Wilde. German Theatre, Ljubljana. Laibacher Zeitung 3 Oct. 1913: 2083.

Rev. of Braut von Messina, by Friedrich Schiller. German Theatre, Ljubljana. Laibacher Zeitung 12 Nov. 1912: 2494.

Rev. of Charley's Aunt, by Brandon Thomas. German Theatre, Ljubljana. Laibacher Zeitung 3 Feb. 1894: 228.

Rev, of Charley's Aunt, by Brandon Thomas. German Theatre, Ljubljana. Laibacher Zeitung 24 March 1896: 546.

Rev. of Der Zerrissene, by Johann Nepomuk Nestroy. German Theatre, Ljubljana. Laibacher Zeitung 7 Feb. 1894: 390.

Rev. of Jane Eyre, adapted by Charlotte Birch-Pfeiffer. German Theatre, Ljubljana. Laibacher Zeitung 4 Nov. 1891: 2110.

Rev. of Jane Eyre, adapted by Charlotte Birch-Pfeiffer. German Theatre, Ljubljana. Laibacher Zeitung 9 Jan. 1897: 47-8.

Rev. of Jane Eyre, adapted by Charlotte Birch-Pfeiffer. German Theatre, Ljubljana. Laibacher Zeitung 14 March 1907: 541.

Rev. of Dorian Gray, based on the novel by Oscar Wilde. German Theatre, Ljubljana. Laibacher Zeitung 28 Nov. 1907: 2560.

Rev. of Dorian Gray, based on the novel by Oscar Wilde. German Theatre, Ljubljana. Laibacher Zeitung 29 Nov. 1907: 2568.

Rev. of Faust, by Johann Wolfgang von Goethe. German Theatre, Ljubljana. Laibacher Zeitung 29 Oct. 1912: 2376.

Rev. of Hamlet, by William Shakespeare. German Theatre, Ljubljana. Laibacher Zeitung 6 March 1908: 478.

Rev. of Hamlet, by William Shakespeare. German Theatre, Ljubljana. Laibacher Zeitung 6 March 1908: 478.

Rev. of Hamlet, by William Shakespeare. German Theatre, Ljubljana. Laibacher Zeitung 7 Jan. 1895: 39.

Rev. of Hamlet, by William Shakespeare. German Theatre, Ljubljana. Laibacher Zeitung 8 March 1899: 420.

Rev. of Little Dorrit, based on the novel by Charles Dickens. German Theatre, Ljubljana. Laibacher Zeitung 3 Nov. 1906: 2354.

Rev. of Little Lord Fauntleroy, by Frances Hodgson-Burnett. German Theatre, Ljubljana. Laibacher Zeitung 13 Feb. 1896: 69-70.

Rev. of Little Lord Fauntleroy, by Frances Hodgson-Burnett. German Theatre, Ljubljana. Laibacher Zeitung 16 March 1900: 485-6. 
Rev. of Lumpacivagabundus, by Johann Nepomuk Nestroy. German Theatre, Ljubljana. Laibacher Zeitung 28 Jan. 1907: 203.

Rev. of Miss Hobbs, by Jerome K. Jerome. German Theatre, Ljubljana. Laibacher Zeitung 2 Oct. 1902: 1899.

Rev. of Mrs. Warren's Profession, by George Bernard Shaw. German Theatre, Ljubljana. Laibacher Zeitung 17 Oct. 1907: 2220.

Rev. of Mrs. Warren's Profession, by George Bernard Shaw. German Theatre, Ljubljana. Laibacher Zeitung 18 Oct. 1907: 2226.

Rev. of Nathan der Weise, by Gotthold Ephraim Lessing. German Theatre, Ljubljana. Laibacher Zeitung 4 Nov. 1906: 2268-9.

Rev. of Nora, by Henrik Ibsen. German Theatre, Ljubljana. Laibacher Zeitung 2 Dec. 1893: 2371.

Rev. of Othello, by William Shakespeare. Slovenian Theatre, Ljubljana. Laibacher Zeitung 4 March 1896: 411-12.

Rev. of Othello, by William Shakespeare. German Theatre, Ljubljana. Laibacher Zeitung 9 Dec. 1899: 2244.

Rev. of Romeo and Juliet, by William Shakespeare. German Theatre, Ljubljana. Laibacher Zeitung 1 March 1900: 384.

Rev. of Romeo and Juliet, by William Shakespeare. German Theatre, Ljubljana. Laibacher Zeitung 15 Dec. 1908: 2697.

Rev. of Romeo and Juliet, by William Shakespeare. German Theatre, Ljubljana. Laibacher Zeitung 1 Apr. 1901: 608.

Rev. of Sherlock Holmes, based on the character by Arthur Conan Doyle. German Theatre, Ljubljana. Laibacher Zeitung 15 Feb. 1906: 322.

Rev. of The Little Minister, by James Matthew Barrie. German Theatre, Ljubljana. Laibacher Zeitung 8 Oct. 1908: 2150.

Rev. of The Merchant of Venice, by William Shakespeare. German Theatre, Ljubljana. Laibacher Zeitung 26 March 1896: 554.

Rev. of The Merchant of Venice, by William Shakespeare. Slovenian Theatre, Ljubljana. Laibacher Zeitung 2 Oct. 1897: 2022.

Rev. of A Midsummer Night's Dream, by William Shakespeare. German Theatre, Ljubljana. Laibacher Zeitung 20 Nov. 1899: 2116.

Rev. of The Taming of the Shrew, by William Shakespeare. German Theatre, Ljubljana. Laibacher Tagblatt 12 Jan. 1875, n. p.

Rev. of The Taming of the Shrew, by William Shakespeare. German Theatre, Ljubljana. Laibacher Zeitung 23 Dec. 1893: 2532. 
Performances of English Plays at the German Theatre in Ljubljana (1875-1916)

\begin{tabular}{|l|l|}
\hline Premiere & \multicolumn{1}{|c|}{ Title (author/translator). Notes. } \\
\hline $09 / 01 / 1875$ & The Taming of the Shrew (Shakespeare) \\
\hline $03 / 11 / 1891$ & $\begin{array}{l}\text { Jane Eyre (Die Waise von Lowood) (adapted from Charlotte Brontë by } \\
\text { Ch. Birch-Pfeiffer) }\end{array}$ \\
\hline $13 / 03 / 1893$ & $\begin{array}{l}\text { Jane Eyre (Die Waise von Lowood) (adapted from Charlotte Brontë by } \\
\text { Ch. Birch-Pfeiffer) }\end{array}$ \\
\hline $19 / 12 / 1893$ & Sweet Lavender (Zwei Rosen) (A. W. Pinero) \\
\hline $22 / 12 / 1893$ & The Taming of the Shrew (Shakespeare) \\
\hline $22 / 01 / 1894$ & Othello (Shakespeare) \\
\hline $01 / 02 / 1894$ & Charley's Aunt (Brandon Thomas). Repeated Feb. 2, 3 and 14. \\
\hline $05 / 01 / 1895$ & Hamlet (Shakespeare) \\
\hline $14 / 02 / 1895$ & $\begin{array}{l}\text { Jane Eyre (Die Waise von Lowood) (adapted from Charlotte Brontë by } \\
\text { Ch. Birch-Pfeiffer) }\end{array}$ \\
\hline $27 / 03 / 1895$ & A Midsummer Night's Dream (Shakespeare) \\
\hline $11 / 01 / 1896$ & Little Lord Fauntleroy (F. Hodgson Burnett). Repeated Jan 20. \\
\hline $23 / 03 / 1896$ & Charley's Aunt (Brandon Thomas) \\
\hline $25 / 03 / 1896$ & The Merchant of Venice (Shakespeare) \\
\hline $08 / 01 / 1897$ & $\begin{array}{l}\text { Jane Eyre (Die Waise von Lowood) (adapted from Charlotte Brontë by } \\
\text { Ch. Birch-Pfeiffer) }\end{array}$ \\
\hline $08 / 03 / 1899$ & Hamlet (Shakespeare) \\
\hline $09 / 11 / 1899$ & Charley's Aunt (Brandon Thomas) \\
\hline $19 / 11 / 1899$ & A Midsummer Night's Dream (Shakespeare) \\
\hline $07 / 12 / 1899$ & Othello (Shakespeare) \\
\hline $05 / 01 / 1900$ & The Taming of the Shrew (Shakespeare) \\
\hline $28 / 02 / 1900$ & Romeo and Juliet (Shakespeare) \\
\hline $15 / 03 / 1900$ & Little Lord Fauntleroy (F. Hogson Burnett) \\
\hline $31 / 03 / 1901$ & Romeo and Juliet (Shakespeare) \\
\hline $31 / 12 / 1901$ & Charley's Aunt (Brandon Thomas) \\
\hline $01 / 10 / 1902$ & Miss Hobbs (Jerome K. Jerome) \\
\hline $14 / 02 / 1906$ & Sherlock Holmes (adapted from A. Conan Doyle) \\
\hline $02 / 11 / 1906$ & Little Dorrit (adapted from Dickens) \\
\hline $16 / 01 / 1907$ & An Ideal Husband (Wilde). Repeated Jan. 23. \\
\hline $13 / 03 / 1907$ & $\begin{array}{l}\text { Jane Eyre (Die Waise von Lowood) (adapted from Charlotte Brontë by } \\
\text { Ch. Birch-Pfeiffer) }\end{array}$ \\
\hline $02 / 10 / 1907$ & A Midsummer Night's Dream (Shakespeare) \\
\hline
\end{tabular}




\begin{tabular}{|l|l|}
\hline $16 / 10 / 1907$ & Mrs. Warren's Profession (Shaw). Repeated Nov. 14. \\
\hline $27 / 11 / 1907$ & Dorian Gray (adapted from Wilde) \\
\hline 20/02/1908 & Charley's Aunt (Brandon Thomas) \\
\hline $04 / 03 / 1908$ & Hamlet (Shakespeare) \\
\hline $07 / 10 / 1908$ & The Little Minister (J.M. Barrie) \\
\hline 14/12/1908 & Romeo and Juliet (Shakespeare) \\
\hline $01 / 02 / 1911$ & The Merchant of Venice (Shakespeare) \\
\hline 09/01/1916 & Charley's Aunt (Brandon Thomas). Repeated Oct. 19. \\
\hline $04 / 02 / 1916$ & Sherlock Holmes (adapted from A. Conan Doyle) \\
\hline
\end{tabular}

\section{Performances of English Plays at the Burgtheater in Vienna}

\begin{tabular}{|l|l|}
\hline Premiere & \multicolumn{1}{|c|}{ Title (author/translator). Notes. } \\
\hline $17 / 11 / 1889$ & King Lear (Shakespeare) \\
\hline $14 / 12 / 1889$ & Much Ado About Nothing (Shakespeare) \\
\hline $31 / 12 / 1889$ & A Winter's Tale (Shakespeare) \\
\hline $13 / 02 / 1890$ & The Taming of the Shrew (Shakespeare) \\
\hline $09 / 04 / 1890$ & Twelfth Night (Shakespeare) \\
\hline $10 / 05 / 1890$ & Henry V (Shakespeare) \\
\hline $02 / 06 / 1890$ & Henry IV (Part 1) (Shakespeare) \\
\hline $12 / 06 / 1890$ & Henry IV (Part 2) (Shakespeare) \\
\hline $05 / 07 / 1890$ & Richard II (Shakespeare) \\
\hline $31 / 12 / 1890$ & Der Maskenball (original not identifiable; trans. Christiane Gräfin \\
\hline Thun) \\
\hline $31 / 10 / 1891$ & Macbeth (Shakespeare) \\
\hline $29 / 02 / 1892$ & Richard III (Shakespeare) \\
\hline $31 / 03 / 1892$ & Henry VI (Part 1) (Shakespeare) \\
\hline $11 / 05 / 1892$ & Henry VI (Part 2) (Shakespeare) \\
\hline $11 / 10 / 1894$ & Antony and Cleopatra (Shakespeare) \\
\hline $05 / 12 / 1894$ & A Midsummer Night's Dream (Shakespeare) \\
\hline $05 / 04 / 1895$ & Coriolanus (Shakespeare) \\
\hline $15 / 04 / 1896$ & Antony and Cleopatra (Shakespeare) \\
\hline $27 / 04 / 1898$ & The Comedy of Errors (Shakespeare) \\
\hline $03 / 05 / 1901$ & Richard II (Shakespeare) \\
\hline $18 / 01 / 1902$ & Troilus and Cressida (Shakespeare) \\
\hline
\end{tabular}




\begin{tabular}{|c|c|}
\hline $13 / 03 / 1902$ & Measure for Measure (Shakespeare) \\
\hline $27 / 02 / 1904$ & Quality Street (Im stillen Gäßchen) (J.M.Barrie/B. Pogson) \\
\hline $17 / 03 / 1906$ & You Never Can Tell (Shaw) \\
\hline $22 / 12 / 1907$ & Julius Caesar (Shakespeare) \\
\hline $09 / 03 / 1908$ & The Little Minister (Barrie) \\
\hline $22 / 04 / 1909$ & A Florentine Tragedy (Wilde) \\
\hline $23 / 12 / 1909$ & The Merchant of Venice (Shakespeare) \\
\hline $13 / 05 / 1910$ & An Ideal Husband (Wilde) \\
\hline $16 / 06 / 1910$ & Richard III (Shakespeare) \\
\hline $23 / 03 / 1911$ & The Builder of Bridges (Dorothy's Rettung) (Sutro) \\
\hline $28 / 03 / 1912$ & Caesar and Cleopatra (Shaw) \\
\hline $01 / 02 / 1913$ & The Lottery Man (Wie man einen Mann gewinnt) (R.J. Young) \\
\hline $16 / 10 / 1913$ & Pygmalion (Shaw) \\
\hline $15 / 02 / 1914$ & Romeo and Juliet (Shakespeare) \\
\hline $28 / 03 / 1914$ & Othello (Shakespeare) \\
\hline $30 / 05 / 1914$ & Richard II (Shakespeare) \\
\hline $11 / 03 / 1916$ & Twelfth Night (Shakespeare) \\
\hline $08 / 06 / 1916$ & King Lear (Shakespeare) \\
\hline
\end{tabular}

The following earlier Burgtheater productions continued to be staged into the period surveyed:

\begin{tabular}{|l|l|}
\hline $27 / 05 / 1850$ & Julius Caesar (Shakespeare). Staged until 30.09.1888. \\
\hline $13 / 02 / 1851$ & Hamlet (Shakespeare). Staged until 11.12.1909. \\
\hline $10 / 12 / 1853$ & $\begin{array}{l}\text { Jane Eyre (Die Waise aus Lowood) (adapted from Charlotte Brontë by } \\
\text { Charlotte Birch-Pfeiffer). Staged until 03.03.1895. }\end{array}$ \\
\hline $20 / 09 / 1862$ & A Winter's Tale (Shakespeare). Staged until 04.10.1888. \\
\hline $30 / 01 / 1875$ & Richard II (Shakespeare). Staged until 01.01.1888. \\
\hline $22 / 02 / 1875$ & Henry IV (Part 1) (Shakespeare). Staged until 18.03.1888. \\
\hline $04 / 03 / 1875$ & Henry IV (Part 2) (Shakespeare). Staged until 20.03.1888. \\
\hline $19 / 03 / 1875$ & Henry V (Shakespeare). Staged until 08.04.1888. \\
\hline $10 / 10 / 1877$ & Macbeth (Shakespeare). Staged until 02.02.1888. \\
\hline $13 / 06 / 1880$ & Romeo and Juliet (Shakespeare). Staged until 29.06.1911. \\
\hline $21 / 06 / 1880$ & The Merchant of Venice (Shakespeare). Staged until 26.06.1888. \\
\hline $02 / 12 / 1881$ & Othello (Shakespeare). Staged until 15.12.1895. \\
\hline $11 / 05 / 1885$ & Much Ado About Nothing (Shakespeare). Staged until 11.04.1888. \\
\hline $16 / 01 / 1886$ & Twelfth Night (Shakespeare). Staged until 06.09.1888. \\
\hline
\end{tabular}




\section{Performances of English Plays at the Volkstheater in Vienna}

\begin{tabular}{|l|l|}
\hline Premiere & \multicolumn{1}{|c|}{ Title (author/translator). Notes. } \\
\hline $12 / 09 / 1891$ & $\begin{array}{l}\text { Jane Eyre (Die Waise von Lowood) (adapted from Charlotte Brontë } \\
\text { by Charlotte Birch-Pfeiffer) }\end{array}$ \\
\hline $26 / 04 / 1892$ & The Taming of the Shrew (Shakespeare) \\
\hline $11 / 02 / 1893$ & The Comedy of Errors (Shakespeare) \\
\hline $01 / 02 / 1895$ & Masqueraders (Schattenspiel) (A.F. Jones) \\
\hline $21 / 09 / 1895$ & Romeo and Juliet (Shakespeare) \\
\hline $28 / 12 / 1895$ & Little Lord Fauntleroy (F.H. Burnett) \\
\hline $17 / 02 / 1896$ & Twelfth Night (Shakespeare) \\
\hline $11 / 03 / 1897$ & Hamlet (Shakespeare) \\
\hline $03 / 04 / 1898$ & Othello (Shakespeare) \\
\hline $10 / 11 / 1900$ & The Gay Lord Quex (Pinero) \\
\hline $04 / 01 / 1902$ & Miss Hobbs (Jerome K. Jerome) \\
\hline $05 / 01 / 1903$ & The Merchant of Venice (Shakespeare) \\
\hline $12 / 12 / 1903$ & Salome (Wilde) \\
\hline $30 / 04 / 1904$ & The Tyranny of Tears (Chambers-Haddon) \\
\hline $08 / 10 / 1904$ & Candida (Shaw) \\
\hline $09 / 12 / 1905$ & $\begin{array}{l}\text { The Importance of Being Earnest (Eine triviale Komödie für seriöse } \\
\text { Leute) (Wilde) }\end{array}$ \\
\hline $25 / 12 / 1905$ & The Adventures of Sherlock Holmes (H. MacNaughten) \\
\hline $11 / 02 / 1906$ & Leah Kleschna (MacLellan) \\
\hline $12 / 03 / 1906$ & The Merry Wives of Windsor (Shakespeare) \\
\hline $01 / 02 / 1907$ & A Woman of No Importance (Wilde) \\
\hline $13 / 04 / 1907$ & His House in Order (Pinero) \\
\hline $27 / 04 / 1907$ & Man and Superman (Shaw) \\
\hline $25 / 05 / 1907$ & Salome (Wilde) \\
\hline $23 / 09 / 1907$ & Richard III (Shakespeare) \\
\hline $28 / 04 / 1908$ & The Philanderer (Shaw) \\
\hline $12 / 09 / 1908$ & Mrs Warren's Profession (Shaw) \\
\hline $27 / 03 / 1909$ & Major Barbara (Shaw) \\
\hline $28 / 06 / 1909$ & The Philanderer (Shaw) \\
\hline $27 / 11 / 1909$ & The Doctor's Dilemma (Shaw) \\
\hline $09 / 02 / 1910$ & Jack Straw (Mein Freund Jack) (Somerset Maugham) \\
\hline $05 / 03 / 1910$ & $\begin{array}{l}\text { The Passing of the Third Floor Back (Der Fremde) (Jerome K. } \\
\text { Jerome) }\end{array}$ \\
\hline
\end{tabular}




\begin{tabular}{|l|l|}
\hline $14 / 08 / 1910$ & Hamlet (Shakespeare) \\
\hline $18 / 03 / 1911$ & Misalliance (Shaw) \\
\hline $27 / 03 / 1911$ & Othello (Shakespeare) \\
\hline $14 / 10 / 1912$ & Romeo and Juliet (Shakespeare) \\
\hline $14 / 08 / 1913$ & Arms and the Man (Helden) (Shaw) \\
\hline $20 / 08 / 1913$ & Salome (Wilde) \\
\hline $18 / 03 / 1916$ & The Devil's Disciple (Shaw) \\
\hline $05 / 10 / 1916$ & A Winter's Tale (Shakespeare) \\
\hline $22 / 02 / 1917$ & The Taming of the Shrew (Shakespeare) \\
\hline
\end{tabular}

